\title{
Seroprevalence of bluetongue in sheep and goats in Egypt
}

\author{
M. A. Mahmoud and Manal H. Khafagi \\ Department of Parasitology and Animal Diseases, \\ Veterinary Research Division, National Research Center, Dokki - 12622, Giza, Egypt. \\ Corresponding author: M. A. Mahmoud, email: m_elfatatri@yahoo.com \\ Received: 22-01-2014, Revised: 25-02-2014, Accepted: 07-03-2014, Published online: 04-04-2014
}

doi: $10.14202 /$ vetworld.2014.205-208

How to cite this article: Mahmoud MA and Khafagi MH (2014) Seroprevalence of bluetongue in sheep and goats in Egypt, Veterinary World 7(4): 205-208.

\begin{abstract}
Aim: The study was undertaken to understand the epidemiological status of bluetongue infection in Egypt.

Materials and Methods: Serum samples were collected from clinically healthy as well as suspected sheep and goats. Samples were collected during the vector breeding season from September to November 2010, from 14 Egyptian governorates which represent different geographical regions of Egypt, and were tested by Agar Gel Immuno-precipitation Test (AGPT).

Results: Out of total 1293 animal serum samples (sheep-1028 and goats-265), 17.5\% of sheep and 14.7\% of goats serum samples were found positive. The overall prevalence of anti-BT antibodies in different governorates was $16.9 \%$. The highest prevalence of bluetongue group specific antibodies was detected in Beni-Suef, Giza, and Al Sharqia governorates (13.2\%). The results indicate that there is a necessity to run further studies to identify the negative governorates. In addition, there is a lack in information regarding the BTV serotypes in Egypt.

Conclusion: This study reflected high seroprevalence of bluetongue infection in sheep than goats. The results indicated that further studies are needed to identify the vectors from different agro-climatic zones, in addition, the BTV serotypes that are circulating in Egypt.
\end{abstract}

Keywords: antibody, bluetongue, goat, sheep, prevalence, virus, Egypt.

\section{Introduction}

Bluetongue (BT) is an infectious non contagious insect-born viral disease of sheep. The causative agent is a double-stranded RNA virus (genus Orbivirus, family Reoviridae) which infects domesticated and wild ruminants [1]. 24 distinct bluetongue virus (BTV) serotypes have been identified for decades. All of them are capable to initiate the disease in ruminants. However, 2 new bluetongue virus serotypes, BTV-25 (Toggenburg orbivirus, from Switzerland) and BTV-26 (from Kuwait), were recently identified in goat and sheep respectively [2].

The disease affects fine wool and mutton breeds of sheep severely. Cattle are considered the main mammalian reservoir of the bluetongue virus and play a very important role in the epidemiology of the disease [3].The virus can infect goats and wild ruminants but usually with mild or no clinical signs $[4,5]$. Although arthropod vectors of the genus Culicoides mainly transmit bluetongue [6], the virus sometimes transmits either via an oral route or vertically in sheep and cattle $[7,8]$. Epidemiological observation showed that bluetongue infection is endemic in tropical areas of the world but without clear clinical signs in the local sheep populations [3]. The distribution of bluetongue is effectively restricted to a latitudinal band around the world between $50^{\circ} \mathrm{N}$ and $30^{\circ} \mathrm{S}$ in America. In the rest of

Copyright: The authors. This article is an open access article licensed under the terms of the Creative Commons Attribution License (http://creativecommons.org/licenses/by/2.0) which permits unrestricted use, distribution and reproduction in any medium, provided the work is properly cited. the world, the latitudinal band is between $40^{\circ} \mathrm{N}$ and $35^{\circ} \mathrm{S}$ where Culicoides midges are extremely abundant [9]. The first confirmed outbreak of bluetongue disease was reported in island of Cyprus [10]. BTV has not been identified in Antarctica continent until now [8].

Clinical signs of the disease are generally clear in sheep and some wild ruminants, but are uncommon in goats and cattle. However special serotypes like serotype 8 have clinically affected mainly cattle in Europe. Symptoms range from subclinical to acute febrile response. It is characterized by inflammation and congestion leading to facial edema and hemorrhages, ulceration of the mucous membranes. It may extend to other parts of the body particularly the groin, axilla, and perineum. There is often severe muscle degeneration and sheep may become lame because of cornitis (inflammation of the coronary bands of the hoof), or skeletal myopathy $[4,5,11]$.

In Egypt, the first documented outbreak of BTV infection occurred in imported Marino sheep [12].The reported BTV serotypes in the subsequent outbreaks were BTV-1,4, 10,12 and 16) [13].

Worldwide distribution of BT disease is attributed to the existence of susceptible species or breeds of ruminants to the virus in temperate climate areas where bluetongue virus is endemic [14].

However, variation in the pathogenesis of strains of bluetongue virus has been reported among some serotypes [15]. There is a prerequisite for full epidemiological understanding of the bluetongue status of any country, pathogenicity of the serotypes 


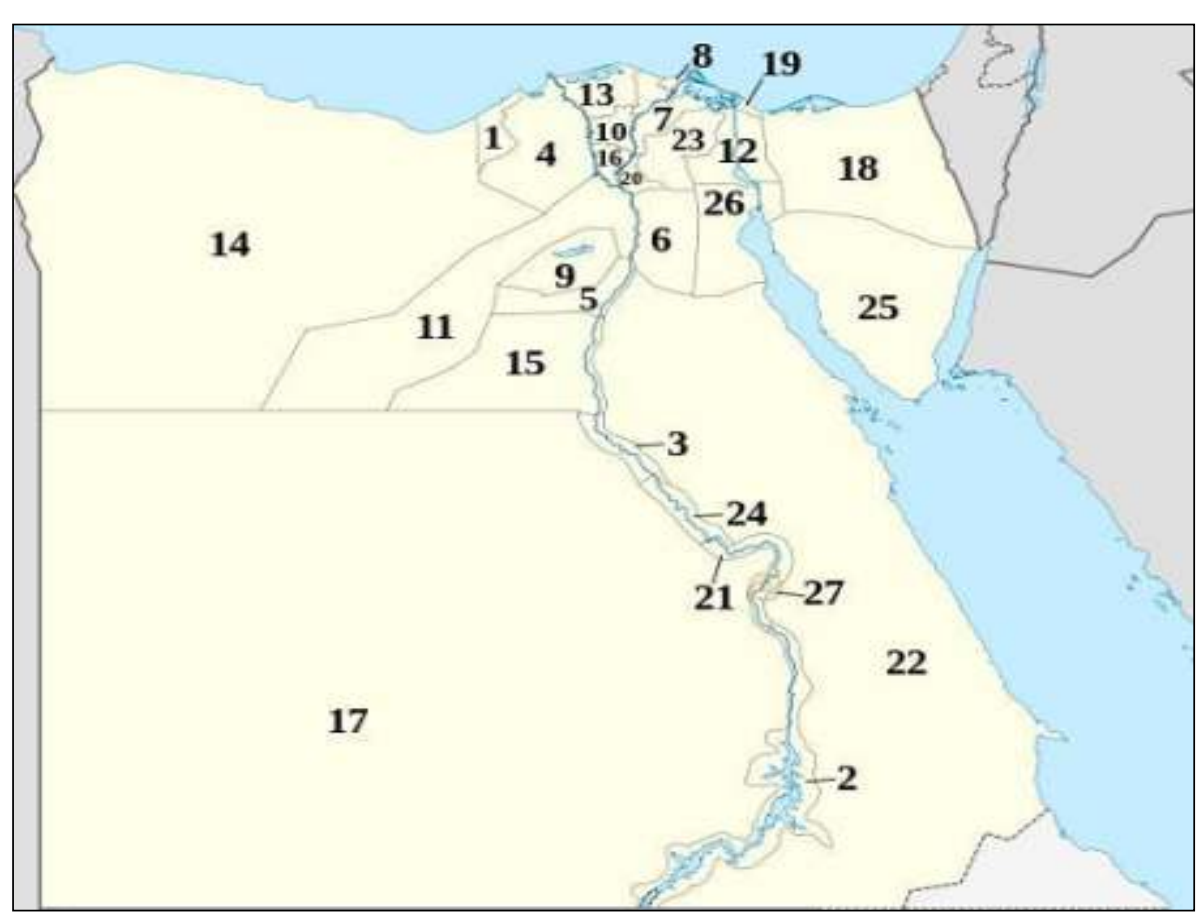

Figure-1. Egyptian governorates map.

(source: http://en.wikipedia.org/wiki/ Governorate_of_Egypt)
Table-1. The governorates names and their key numbers

\begin{tabular}{ll}
\hline Key number & Governorate \\
\hline 1 & Alexandria \\
2 & Aswan \\
3 & Asyut \\
4 & Beheira \\
5 & BeniSuef \\
6 & Cairo \\
7 & Dakahlia \\
8 & Damietta \\
9 & Faiyum \\
10 & Gharbia \\
11 & Giza \\
12 & Ismailia \\
13 & Kafr el-Sheikh \\
14 & Matruh \\
15 & Minya \\
16 & Monufia \\
17 & New Valley \\
18 & North Sinai \\
19 & Port Said \\
20 & Qalyubia \\
21 & Qena \\
22 & Red Sea \\
23 & Al Sharqia \\
24 & Sohag \\
25 & South Sinai \\
26 & Suiz \\
27 & Luxor \\
\hline &
\end{tabular}

Table-2. AGPT for detection of BTV antibodies in the serum samples.

\begin{tabular}{|c|c|c|c|c|c|c|c|c|c|c|}
\hline \multirow{2}{*}{ Governorate } & \multirow{2}{*}{$\begin{array}{c}\text { Key } \\
\text { number }\end{array}$} & \multicolumn{3}{|c|}{ Sheep samples } & \multicolumn{3}{|c|}{ Goats samples } & \multicolumn{3}{|c|}{ Total samples of sheep and goats } \\
\hline & & $\begin{array}{c}\text { No. of } \\
\text { samples }\end{array}$ & Positive & $\begin{array}{c}\text { \% Positive } \\
\text { (of 1028) }\end{array}$ & $\begin{array}{c}\text { No. of } \\
\text { samples }\end{array}$ & Positive & $\begin{array}{l}\text { \% Positive } \\
\text { (of 265) }\end{array}$ & $\begin{array}{c}\text { No. of } \\
\text { samples }\end{array}$ & Positive & $\begin{array}{c}\text { \% Positive } \\
\text { (of 1293) }\end{array}$ \\
\hline Asyut & 3 & 90 & 11 & 1.1 & 30 & 3 & 1.1 & 120 & 14 & 1.1 \\
\hline Biheira & 4 & 100 & 3 & 0.3 & 20 & 0 & 0.0 & 120 & 3 & 0.2 \\
\hline Damietta & 8 & 38 & 0 & 0.0 & 10 & 0 & 0.0 & 48 & 0 & 0.0 \\
\hline Suiz & 26 & 60 & 0 & 0.0 & 0 & 0 & 0.0 & 60 & 0 & 0.0 \\
\hline Minya & 15 & 40 & 4 & 0.4 & 20 & 3 & 1.1 & 60 & 7 & 0.5 \\
\hline Beni-Suef & 5 & 103 & 74 & 7.2 & 17 & 10 & 3.8 & 120 & 84 & 6.5 \\
\hline Al Shargia & 23 & 155 & 45 & 4.4 & 30 & 4 & 1.5 & 185 & 49 & 3.8 \\
\hline Gharbia & 10 & 102 & 9 & 0.9 & 18 & 3 & 1.1 & 120 & 12 & 0.9 \\
\hline Giza & 11 & 80 & 24 & 2.3 & 40 & 14 & 5.3 & 120 & 38 & 2.9 \\
\hline Dakahlia & 7 & 40 & 0 & 0.0 & 20 & 0 & 0.0 & 60 & 0 & 0.0 \\
\hline Qalyubia & 20 & 30 & 2 & 0.2 & 10 & 0 & 0.0 & 40 & 2 & 0.2 \\
\hline Qena & 21 & 60 & 4 & 0.4 & 20 & 2 & 0.8 & 80 & 6 & 0.5 \\
\hline Faiyum & 9 & 90 & 3 & 0.3 & 30 & 0 & 0.0 & 120 & 3 & 0.2 \\
\hline Kafer-el-sheikh & h 13 & 40 & 1 & 0.1 & 0 & 0 & 0.0 & 40 & 1 & 0.1 \\
\hline Total & & 1028 & 180 & 17.5 & 265 & 39 & 14.7 & 1293 & 219 & 16.9 \\
\hline
\end{tabular}

present, isolation and characterization of these viruses. In this paper we studied the prevalence of BTV group specific antibody in 14 governorates of the Upper and Lower Egypt, using Agar Gel Immuno-precipitation Test (AGPT) in randomly collected serum samples from sheep and goats.

\section{Materials and Methods}

Ethical approval: Experiments were carried out in accordance with the guidelines laid down by the International Animal Ethics Committee and in accordance with local laws and regulations.

Serum samples collected for detection of BTV group specific antibodies by AGPT: A total of 1293 sheep and goats serum samples were collected from suspected and clinically healthy sheep (1028) and goats (265) from 14 governorates of the Upper and Lower Egypt representing different geographical regions of the country (Figure-1, Table-1) during the vector breeding season from September to November 2010 and tested by the AGPT (Table-2, Figure-2).

Blood samples: $5 \mathrm{ml}$ of blood was collected aseptically from jugular vein of each animal using anticoagulant free vacutainer tubes and transported on ice to the laboratory. Serum was separated by centrifugation of the blood at $3000 \mathrm{rpm}$ for $10 \mathrm{~min}$ at room temperature; aliquots were transferred into $1.5 \mathrm{ml}$ sterile microtube. All serum samples were stored at $-20^{\circ} \mathrm{C}$ until used for serological investigation.

Agar gel immuno-precipitation test (AGPT): A modification of the AGIDT was used to detect BTV group-specific antibodies according to Taylor and McCausland [16]. Serum samples were tested against BTV antigen (Bluetongue AGID antigen, was obtained from Pirbright England) in agarose isotonic saline 


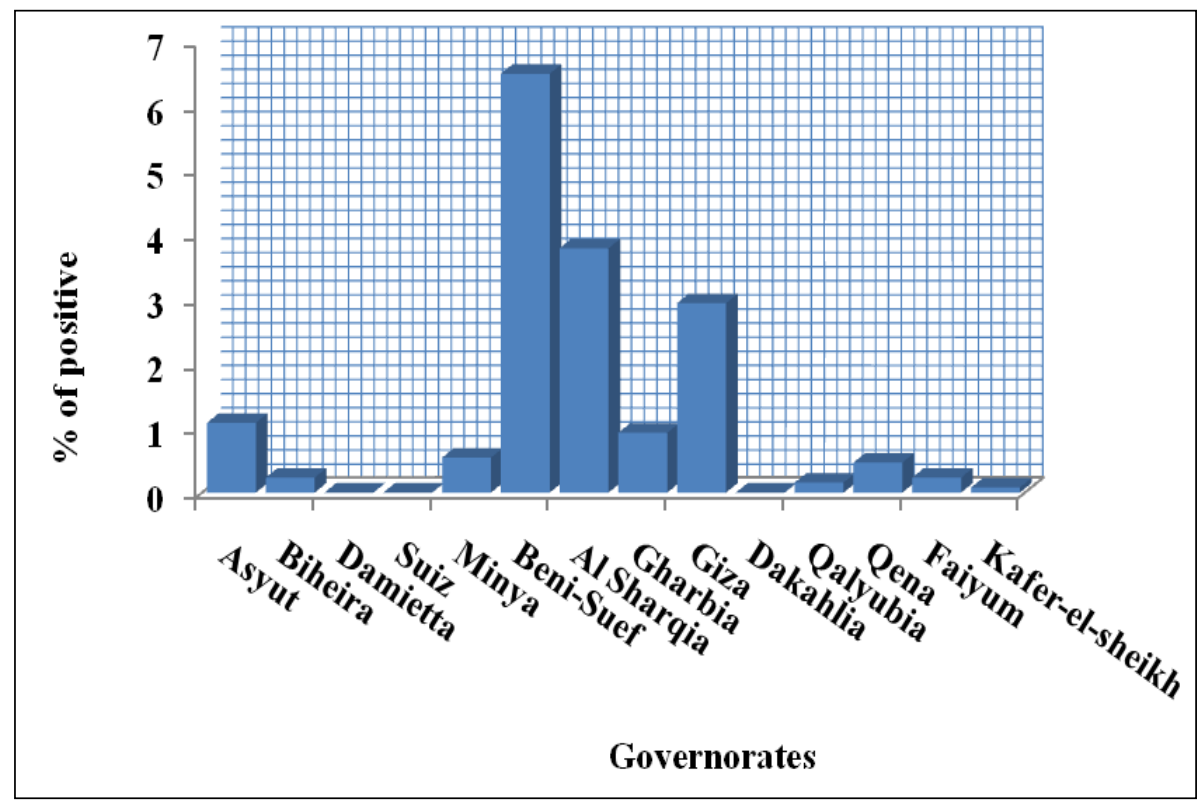

Figure-2. Results of AGPT for detection of BTV specific antibodies in sheep and goats sera collected from different governorates in Egypt.

solution $(0.9 \% \mathrm{NaCl}$ in distilled water). Agarose isotonic saline solution was poured onto Petri dishes to form a layer of $2.5 \mathrm{~mm}$ thickness. Then the plates were allowed to stand open on a horizontal bench for cooling. Seven well patterns $6 \mathrm{~mm}$ in diameter and 2.5 $\mathrm{mm}$ a part were punched in each plate. The antigen was added into the central well while the directed well to the north was filled to the brim with $50-60 \mu$ l of control positive serum. The remaining 5 wells were designed for the serum to be tested. The plates were incubated at room temperature for 48 hours.

Test plates were held at room temperature in a humidified chamber for 24 hours. Serum samples were recorded as positive when the precipitin lines formed lines of identity with the positive-control serum or when they caused the positive control precipitin line to bend toward the antigen well (weak positives).

\section{Results and Discussion}

According to the list of International Office of Epizootics, the Bluetongue disease is classified as a communicable and a wide spreading worldwide disease [17]. Bluetongue is of an economical importance because it causes deleterious effects on the reproductive function such as abortions, early embryonic loss and congenital malformations in the affected ruminants [18]. This study was carried out to throw a light on the situation of this disease in Egyptian animal population through evaluating its seroprevalence, that would help decision makers and stakeholders.

The serological data of BTV is poorly defined in Egypt and limited to the results of a serological survey that was carried out by Hafez and Ozawa [12]. They reported that BTV antibodies were distributed nearly all over the country (9\%) and precipitating antibodies in ovine sera collected from free and endemic areas were about $37 \%$.
Within the examined 1293 sheep and goats serum samples originated from 14 governorates, by AGPT for presence of BT group specific antibodies, the over all antibody prevalence was $16.7 \%$. It demonstrates the high prevalence of anti-BTV agar gel precipitating antibodies in sheep and goats in different governorates that represent different geographical areas in the country. It supports the results, which were previously obtained by Hafez and Ozawa [12].

The average of BTV antibody prevalence was slightly higher in sheep (17.5\%) than in goats (14.7\%) as shown in Table 1. The susceptibility of goats to BT virus was variable, but generally goats were resistant to natural infections [19].

Some governorates like Suiz, Damietta, and Dakahlia showed zero percentage of seropositivity in their samples. Like these governorates, more epidemiological data is required and further examinations of larger number of animals are recommended for complete conclusion about these areas. Other governorates showed low percentage of seropositivity in their samples $(0.1 \%-1.1 \%)$. On the other hand, high percentage of seropositivity in serum samples is recorded in BeniSuef, Al Sharqia and Giza $(6.5 \%, 3.8 \%$ and $2.9 \%$ respectively) although the three governorates are apart and do not share any borders.

The animal susceptibility to the virus infection is attributed to multiple epidemiological factors such as competence, distribution of the vector and feeding habits of the vector. Animal age also plays a role where older animals tend to be more susceptible than younger ones. The severity of clinical signs seems to vary according to the animal breed and the infecting serotype of the virus [20].

Because the AGPT detects BTV group specific antibodies and hence it is not serotype-specific and less sensitive than ELISA, in governorates that show low 
prevalence or zero prevalence like Suiz, Damietta, and Dakahlia, ELISA test is recommended [21].

From these results, we can conclude that AGPT may be sufficient test for monitoring the disease condition in endemic areas but the use of more sensitive techniques that detect the virus antigen are recommended in free areas and international trade where the maximum sensitivity is recommended for more safety.

It should be emphasized here that such investigation protocol has to be repeated encompassing all the 27 governorates to collect updated necessary information about the situation of BT virus in Egypt. Identification and selection of the most prevalent virus serotypes that should be incorporated in polyvalent vaccine, if a vaccination program for BT would be re-established for ruminants, once a clinical disease is reported in Egypt or other countries on the border. Moreover, special attention should be taken to avoid importation of animals from the areas in which recent out breaks occurred, to avoid emergence of the pathogenic serotypes of the virus in Egypt.

\section{Conclusion}

This study reflected high seroprevalence of bluetongue infection in sheep than goats. The results indicated that further studies are needed to identify the vector from different agro-climatic zones and to determine the BTV serotypes that have been circulating in Egypt.

\section{Authors' contributions}

MFM and MHK conceived the study, performed the fieldwork, collected the samples, carried out the laboratory work, analyzed the data, drafted the manuscript. Both author read and approved the final manuscript.

\section{Acknowledgments}

The authors would like to thank the field veterinarians who helped in collection of serum samples and all staff members of ELISA Unit and virus strain bank, Animal Health Research Institute, Dokki, Giza, Egypt. Authors would like to thank Dr. A.M. Allam, Department of Parasitology and Animal Diseases Veterinary Research Division, National Research Center, Dokki - 12622, Giza, Egypt, who reviewed the manuscript. This research was self-funded by authors.

\section{Competing interests}

The authors declare that they have no competing interests.

\section{References}

1. Attoui, H., Maan, S.S., Anthony, S.J. and Mertens, P.P.C. (2009) In: Bluetongue virus, other orbiviruses and other reoviruses: Their relationships and taxonomy, 1 Ed. London: Elsevier/Academic Press; p23-552.

2. Maan S, Maan NS, Nomikou K, Veronesi, E., Bachanek-
Bankowska, K., Belaganalli, M.N., Attoui, H. and Mertens, P.C. (2011) Complete genome characterization of a novel 26th buetongue virus serotype from Kuwait. PLoS One, 6: e26147 doi: 10.1371/journal.pone.0026147.

3. Faes, C., van der Stede, Y., Guis, H., Staubach, C., Ducheyne, E., Hendrickx, G. andMintiens, K. (2013) Factors affecting Bluetongue serotype 8 spread in Northern Europe in 2006: the geographical epidemiology. Prev Vet Med.1;110(2):14958.

4- MacLachlan, N. J., Drew, C.P., Darpel, K. E., and Worwa, G. (2009) The pathology and pathogenesis of blue- tongue. $J$. Comp. Pathol. 141, 1-16.

5. Sperlova, A. and Zendulkova, D. (2011) Bluetongue: a review. Vet. Med-Czech 56(9): 430-452.

6. Saegerman, C., Bolkaerts, B., Baricalla, C., Raes, M., Wiggers, L., De L, I, Leeuw, D. L., Vandenbussche, F., Zimmer, J.Y., Haubruge, E., Cassart, D., Clercq, K.D. and Kirschvink, N. (2011) The impact of naturally-occurring, trans-placental bluetongue virus serotype- 8 infection on reproductive performance in sheep. Vet. J. 187:72-80.

7. Wilson, A.J. and Mellor, P.S. (2009) Bluetongue in Europe: past, present and future. Philosophical Transactions of the Royal Society B: Biological Sciences 364:2669-2681.

8. Maclachlan, N.J. (2010) Global implications of the recent emergence of bluetongue virus in Europe. Veterinary Clinics of North America: food Animal Practice 26:163-171.Bengal.

9. Gard, G.P. and Melville.L.E. (1992) In: Bluetongue, African Horse Sickness and Related Orbivirases. pp. 85, (Eds.) T.E. Walton and B.I. Osburn. C.R.C. Press. Boca Raton. USA.

10. Gambles, R.M. (1949) Bluetongue of sheep in Cyprus. J. Comp. Pathol. 59: 176-190.

11. MacLachlan, N.J., Drew, C.P., Darpel, K.E., Worwa, G. (2009).The pathology and pathogenesis of bluetongue, $J$. Comp. Pathol.141:1-16.

12. Hafez, S. M. and Ozawa, Y. (1973).Serological survey of bluetongue in Egypt. Bull. Epiz. Dis. Afr., 21(3): 297-304.

13. Ismail J.M., Martin Jeggo, and NazmiAyoub.(1987). Bluetongue neutralization test with different virus under variable conditions. Agr. Res. Rev. Egypt. 65(5): 867-872.

14. Gibbs, E.P.J., Lawman, M.J.P. and Herniman, KoA. J., (1979) Preliminary observations on transplacental infection of bluetongue virus in sheep - a possible overwintering mechanism. Res. Vet.Sci., 27: 118-120.

15. Uren, M.F., Blok, J.and Manderson, L.H. (1989) Arbovirus research in Australia: proceedings fifth symposium, Brisbane. CSIRO Division of Tropical Animal Production and Queensland Institute of Medical Research.

16. Taylor, W. P. and McCausland, A. (1976).Studies with bluetongue virus in Nigeria. Trop. Anim. Health Prod., 8, 169-173.

17. Mellor P.S. and Wittmann E.J. (2002) Bluetongue virus in the Mediterranean basin 1998-2001.Vet. J., 164, 20-37.

18. World Organization for Animal Health (2010) Bluetongue, chapter 8.3, Terrestrial Animal Health Code, 19th edition OIE, paris p448-463.

19. Luedke, A. J. and Anakwenze, E. 1.(1972). Bluetongue virus in goats. Am. J. Vet. Res., 33(9): 1739-45.

20. Miller, M.M., Brown, J., Cornish, T., Johnson, G., Mecham, J.O., Reeves, W.K., and William, W.(2010) Investigation of a bluetongue disease epizooticcaused by bluetongue virus serotype 17 in sheep in Wyoming. J Am. Vet. Med. Assoc. 237(8): 955-959.

21. Joardar, S.N., Barkataki, B., Halder, A., Lodh, C. and Sarma, D. (2013). Seroprevalence of bluetongue in north eastern Indian state-Assam, Vet. World .,6(4):196-199. 